\title{
Comparison of amount of postoperative use of blood and blood products between patients receiving and not receiving salicylate before coronary surgery
}

\author{
B Ozcem, U Yetkin", M Bademci, M Akyuz, S Yazman, E Celik, N Karakas, I Yurekli, A Gurbuz \\ From 23rd World Congress of the World Society of Cardio-Thoracic Surgeons \\ Split, Croatia. 12-15 September 2013
}

\section{Background}

In this study, we aimed to present whether there was a significant difference between patients receiving $100 \mathrm{mg}$ salicylate and not receiving salicylate before coronary artery bypass grafting in terms of amount of postoperative use of blood and blood products.

\section{Methods}

Sixty-one patients that underwent coronary bypass surgery in one year at our clinic were investigated retrospectively. Thirty $(49.2 \%)$ of them were receivers of $100 \mathrm{mg}$ entericcoated salicylate and 31 (50.8\%) were non-receivers, divided into 2 groups. The mean age of salicylate receivers was 61.33 years whereas it was 57.71 years in the non-receivers.

\section{Results}

There was no significant difference between groups that underwent on-pump coronary bypass surgery in terms of mean units of blood and blood products used ( $\mathrm{p}>0.05$ ). The percentage of blood product use was $54.5 \%$ in salicylate receivers and $55.6 \%$ in non-receivers. There was no significant difference between groups of patients that underwent off-pump beating heart coronary surgery in terms of amount of blood and blood product used ( $\mathrm{p}>0.05$ ). The percentage of blood product use was $37.5 \%$ in salicylate receivers and $50 \%$ in non-receivers in this group of patients $(\mathrm{p}>0.05)$.

* Correspondence: ufuk_yetkin@yahoo.fr

Department of Cardiovascular Surgery, Izmir Katip Celebi University Ataturk Training and Research Hospital, Izmir, Turkey

\section{Conclusions}

When the amount blood and blood products used was investigated for patients undergoing either on-pump or off-pump coronary bypass in terms of salicylate use, no significant difference was detected between groups.

Published: 11 September 2013

doi:10.1186/1749-8090-8-S1-P80

Cite this article as: Ozcem et al.: Comparison of amount of postoperative use of blood and blood products between patients receiving and not receiving salicylate before coronary surgery. Journal of Cardiothoracic Surgery 2013 8(Suppl 1):P80.
Submit your next manuscript to BioMed Central and take full advantage of:

- Convenient online submission

- Thorough peer review

- No space constraints or color figure charges

- Immediate publication on acceptance

- Inclusion in PubMed, CAS, Scopus and Google Scholar

- Research which is freely available for redistribution

Submit your manuscript at www.biomedcentral.com/submit
C Bïomed Central 